\title{
IMPLEMENTASI TECHNOLOGICAL PEDAGOGICAL CONTENT KNOWLEDGE (TPACK) DALAM PENDIDIKAN PROFESI GURU (PPG) PAI LPTK UIN MATARAM
}

\author{
Abdul Quddus \\ Universitas Islam Negeri Mataram, Indonesia \\ abdul.quddus@uinmataram.ac.id
}

\begin{abstract}
ABSTRAK
Penelitian ini bertujuan untuk menganalisis implementasi pembelajaran Technological Pedagogical Content Knowledge (TPACK) melalui pembelajaran online pada program Pendidikan Profesi Guru (PPG) PAI di LPTK UIN Mataram. Metode penelitian yang digunakan adalah deskripstif kualitatif dengan pendekatan studi kasus. Temuan penelitian ini bahwa implementasi pembelajaran online melalui TPACK di LPTK UIN Mataram dengan 58 Orang mahasiswa dari 7 propinsi telah berhasil meningkatkan kompetensi guru seperti kompetensi manajemen kelas online, download dan baca modul, baca materi dengan file format pdf, powerpoint, menonton video pembelajaran, kemudian resume dan upload tugas, aktif dalam diskusi online dan mengikuti ujian online dalam bentuk pretest, tugas formatif, tugas sumatif, dan tugas akhir modul online. Mahasiswa PPG PAI UIN Mataram lulus Uji Kompetensi Nasional 99\% untuk Uji Kinerja (Ukin) dan $68.42 \%$ untuk Uji Pengetahuan (UP).
\end{abstract}

Kata kunci: Pembelajaran, TPACK, Blended Learning, Pendidikan Profesi Guru, PAI

\begin{abstract}
This study aims to analyze the implementation of Technological Pedagogical Content Knowledge (TPACK) learning through online learning in the PAI Teacher Professional Education (PPG) program at LPTK UIN Mataram. The research method used a qualitative descriptive case study approach. The findings of this study are that the implementation of online learning through TPACK at LPTK UIN Mataram with 58 students from 7 provinces has succeeded in increasing teacher competencies such as online class management competencies, downloading and reading modules, reading material with pdf format files, powerpoints, watching learning videos, then resume and upload assignments, be active in online discussions and take online exams in the form of pretests, formative, summative, and final exam based on online modules. Students of PPG PAI UIN Mataram finished the 99\% National Competency Test for Performance Test (Ukin) and $68.42 \%$ for Knowledge Test (UP).
\end{abstract}

Keywords: Learning, TPACK, Blended Learning, Teacher Professional Education, PAI 


\section{PENDAHULUAN}

Era revolusi industri 4.0 dengan kemajauan informasi teknologi sebagai karakteristiknya telah telah berpengaruh cepat pada dunia pendidikan. Sistem pendidikan pun terus mengalami perkembangan dari yang hanya menggunakan sistem konvensional beralih ke sistem yang serba digital. Pada awalnya proses belajar mengajar hanya terjadi di ruang kelas, namun sekarang proses belajar mengajar tak terikat oleh ruang dan waktu, sehingga guru dituntut harus menguasai teknologi sebagai media pendukung dalam kegiatan pembelajaran tersebut.

North American Council for Online Learning (NACOL) telah melakukan riset dan mempraktikkan beberapa model teknologi dalam pembelajaran, seperti model pembelajaran campuran (blended learning). Menurut Semler (2005) "Blended learning combines the best aspects of online learning, structured face-to-face activities, and real world practice. Online learning systems, classroom training, and on-the-job experience have major drawbacks by themselves. The blended learning approach uses the strengths of each to counter the others' weaknesses." Blended Learning tidak terfokus pada kegiatan tatap muka dikelas (face to face), tetapi menggunakan juga teknologi berbasis web (online learning). Blended learning memberikan kesempatan yang terbaik untuk belajar dari kelas transisi ke e-learning. Blended learning melibatkan kelas (atau tatap muka) dan belajar online. Metode ini sangat efektif untuk menambah efisiensi untuk kelas instruksi dan memungkinkan peningkatan diskusi atau meninjau informasi di luar ruang kelas.

Selain penggunaan teknologi sebagai media belajar, dalam framework TPACK, pedagogi adalah aspek penting yang perlu diperhatikan dalam kegiatan pembelajaran. Pedagogi bukan saja bagaimana mengembangkan seni-seni dalam mengajar, atau mendesain kelengkapan instrumeninstrumen proses dan penilaian dalam pembelajaran, namun dituntut juga memahami siswa secara psikologis dan biologis. 
Amanat Undang-undang Nomor 14 Tahun 2005 tentang Guru dan Dosen pasal 8 menyebutkan bahwa Guru wajib memiliki kualifikasi akademik, kompetensi, sertifikat pendidik, sehat jasmani dan rohani, serta memiliki kemampuan untuk mewujudkan tujuan pendidikan nasional. Dalam Undangundang Nomor 12 Tahun 2012 tentang Pendidikan Tinggi pasal 17 ayat (1) menyatakan bahwa pendidikan profesi merupakan pendididkan tinggi setelah program sarjana yang menyiapkan mahasiswa dalam pekerjaan yang memerlukan persyaratan keahlian khusus. Penyiapan Guru sebagai pendidik profesional dinyatakan pula pada Peraturan Pemerintah Nomor 19 Tahun 2017 tentang Perubahan atas Peraturan Pemerintah Nomor 74 Tahun 2008 tentang Guru 74 tahun 2008 tentang Guru. Regulasi tersebut melandasi terjadinya reformasi guru di Indonesia dimana guru harus disiapkan melalui pendidikan profesi setelah program sarjana. Program PPG dan meningkatkan mutu proses pendidikan dan pembelajaran sesuai dengan Permenristekdikti No. 44 Tahun 2015 tentang Standar Nasional Pendidikan Tinggi (SN-Dikti) dan Permenristekdikti No. 55 Tahun 2017 tentang Standar Pendidikan Guru. Melalui peningkatan mutu proses pendidikan dan pembelajaran ini diharapkan dapat menghasilkan lulusan calon guru yang siap menghadapi tantangan dan peluang kehidupan yang semakin kompleks di abad 21 dan siap bersaing di era Masyarakat Ekonomi Asean (MEA), dan global.

Program Studi Pendidikan Profesi Guru (PPG) merupakan program pendidikan yang diselenggarakan untuk mempersiapkan lulusan S1 Kependidikan dan S1/D IV Non Kependidikan yang memiliki bakat dan minat menjadi guru agar menguasai kompetensi guru secara utuh sesuai dengan standar nasional pendidikan sehingga dapat memperoleh sertifikat pendidik profesional pada pendidikan anak usia dini, pendidikan dasar, dan pendidikan menengah. Program Studi Pendidikan Profesi Guru (PPG) diharapkan dapat menjawab berbagai permasalahan pendidikan, seperti: (1) kekurangan jumlah guru (shortage) khususnya pada daerah-daerah terluar, terdepan, dan tertinggal, (2) distribusi tidak seimbang (unbalanced 
distribution), (3) kualifikasi di bawah standar (under qualification), (4) guruguru yang kurang kompeten (low competence), serta (5) ketidaksesuaian antara kualifikasi pendidikan dengan bidang yang diampu (missmatched). (Lihat Panduan PPG Direktorat Pembelajaran Ditjen Belmawa, 2018)

Program Studi Pendidikan Profesi Guru (PPG) yang akan menghasilkan guru-guru profesional diharapkan akan menghasilkan lulusan yang unggul dan siap menghadapi tuntutan zaman. Posisi hasil belajar siswa di Indonesia saat ini belum menggembirakan. Hasil studi PISA (Program for International Student Assessment) tahun 2015 menunjukkan bahwa Indonesia baru bisa menduduki peringkat 69 dari 76 negara, demikian juga hasil studi TIMSS (Trends in International Mathematics and Science Study), juga menunjukkan siswa Indonesia berada pada ranking 36 dari 49 negara dalam hal melakukan prosedur ilmiah. (Mohammad Tohir, 2019)

Program Studi Pendidikan Profesi Guru (PPG) yang dirancang secara sistematis dan menerapkan prinsip mutu mulai dari seleksi, proses pembelajaran dan penilaian, hingga uji kompetensi, diharapkan akan menghasilkan guru-guru masa depan yang profesional yang dapat menghasilkan lulusan yang unggul, kompetitif, dan berkarakter, serta cinta tanah air.

Universitas Islam Negeri (UIN) Mataram ditunjuk sebagai salah satu Perguruan Tinggi Keagamaan Islam Negeri (PTKIN) penyelengggara Pendidikan Profesi Guru (PPG) berdasarkan Keputusan Menteri Agama (KMA) Nomor 606 Tahun 2018 tanggal 11 Oktober 2018 bersama 35 PTKIN lainnya. Tahun 2019 LPTK UIN Mataram mendapatkan kuota 58 orang guru PAI dari tujuh provisi dan 185 guru madrasanh dari Nusa Tenggara Barat (NTB).

\section{LANDASAN TEORI}

Technological Pedadogical Contents Knowledge (TPACK) adalah model yang digunakan untuk integrasi teknologi ke pendidikan. Model ini 
melengkapi model PCK yang sudah dikembangkan lebih dulu oleh Schulman (1986). Penambahan unsur technological knowledge diusulkan pertama kali oleh Pierson (2001) untuk memperbaiki model yang dikembangkan Schulman. Model yang dikembangkan menjadi model TPCK dan dipakai sebagai salah satu model terkait integrasi teknologi pada bidang pengajaran. Mishra and Koehler (2007) mengusulkan nama baru untuk TPCK menjadi TPACK, sehingga menjadi lebih mudah diucapkan dan diingat.

Mishra dan Koehler (2006) dengan judul Technological Pedagogical Content Knowledge : A framework for Teacher Knowledge, sejak dikenalkan 2006 sampai dengan 2019 ini masih menjadi kerangka teori utama bagi peneliti dan praktisi pendidikan dalam upaya mengembangkan beberapa model pembelajaran. Istilah yang kemudian dikenal dengan TPACK (Technological, Pedagogical, Content Knowledge) adalah sebuah framework (kerangka kerja) dalam mendesain model pembelajaran baru dengan menggabungkan tiga aspek utama yaitu teknologi, pedagogi dan konten/materi pengetahuan (ontologis)

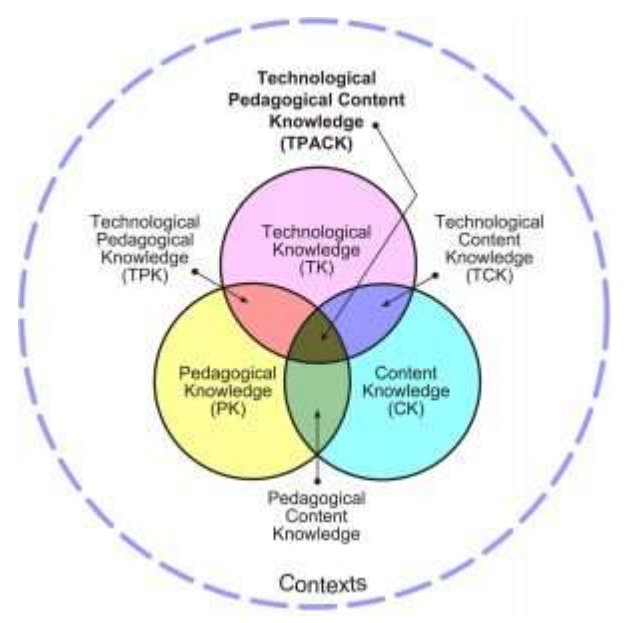

Gambar 1. Kerangka TPACK dan Komponen Pengetahuan

Dalam model kerangka TPACK dalam gambar 1 di atas, ada tiga komponen pengetahuan guru yaitu materi bidang studi, pedagogi dan teknologi. Model ini memiliki tiga interseksi yang sama penting yaitu 
interseksi antara badan pengetahuan yang dinyatakan sebagai PCK (pedagogical content knowledge), TCK (technological content knowledge), TPK (technological pedagogical knowledge), and TPACK (technology, pedagogy,and content knowledge).

Pada irisan 3 tipe pengetahuan adalah pemahaman intuitif pengajaran konten dengan metode pedagogi dan teknlogi yang sesuai. tujuh komponen yang termasuk kedalam kerangka TPACK adalah: 1) Technology knowlegde (TK): TK merupakan pengetahuan tentang berbagai teknologi dari mulai teknologi rendah (low tech) seperti pensil dan kertas ke teknologi digital seperti internet, video, interactive whiteboard, dan program software. 2) Content knowlegde (CK): $\mathrm{CK}$ adalah pengetahuan tentang materi keilmiah yang akan dibelajarkan atau diajarkan (Mishra \& Koehler, 2006, p. 1026). Seorang guru harus mengetahui tentang konten pengetahuan yang akan mereka ajarkan. 3) Pedagogical knowledge (PK): PK berhubungan dengan metode dan proses mengajar dan termasuk pengetahuan dalam manajemen kelas, penilaian, pengembangan rencana pembelajaran (RPP), dan belajar siswa. 4) Pedagogical content knowledge (PCK): PCK berhubungan dengan pengetahuan konten yang berhubungan dengan proses mengajar (Shulman,1986). PCK berbeda dengan berbagai jenis konten, karena PCK merupakan perpaduan antara konten dan pedagogi dengan tujuan untuk mengembangkan praktek mengajar suatu konten yang lebih baik. 5) Technological content knowledge (TCK): TCK merupakan pengetahuan tentang bagaimana teknologi bisa mencipkan representasi yang baru untuk konten yang spesifik. Dengan menggunakan teknologi yang spesifik, guru bisa mengubah cara guru berlatih dan memahami konsep di dalam konten spesifik. 6) Technological pedagogical knowledge (TPK): TPK merupakan pengetahuan tentang bagaimana berbagai teknologi bisa digunakan dalam mengajar dan untuk memahami bahwa penggunaan teknologi dapat merubah cara guru mengajar. 7) Technological pedagogical content knowledge (TPACK): TPACK berhubungan dengan pengetahuan yang 
dibutuhkan oleh guru untuk mengintegrasikan teknologi ke dalam pengajaran konten tertentu. Guru memiliki pemahaman intuitif mengenai interaksi kompleks antara tiga komponen dasar pengetahuan (konten, pedagogi, teknologi) dengan mengajarkan konten menggunakan metode pedagogik dan teknologi yang sesuai.

Pendekatan TPACK merupakan pendekatan pembelajaran yang memadukan antara materi, pedagogi dan teknologi (So \& Kim, 2009; Bozkurt, 2014; Khan, 2011; Park, Jang, \& Chen, 2011). Pendekatan TPACK dapat diintegrasikan dengan model yang dapat melatih siswa untuk menemukan pengetahuan baru secara mandiri namun tetap mendapat bimbingan guru

\section{METODE}

Penelitian ini dilakukan di LPTK UIN Mataram, khususnya pada program Pendidikan Profesi Guru (PPG) PAI dengan menggunakan pendekatan penelitian kualitatif. Peneliti adalah instrumen kunci dalam mengumpulkan data dan menafsirkan data (Moleong, 2000, 5). Alat pengumpulan data menggunakan pengamatan langsung, wawancara, studi dokumen. Sedangkan kesahihan dan keterandalan data menggunakan triangulasi dengan menggunakan metode induktif. Selanjutnya Dalam penelitian ini, analisis data dilakukan secara berkesinambungan dari awal sampai akhir penelitian, baik dilapangan maupun diluar lapangan dengan memperguanakan teknik seperti yang dikemukan oleh Miles dan huberman: reduksi data, display, Verifikasi dan kesimpulan. (Miles dan Huberman, 1992, 19)

\section{HASIL DAN PEMBAHASAN}

Idealnya Pemanfaatan TPACK digunakan dalam sistem penugasan seperti reading report, chapter report, book review, mini research, research project, dimana semuanya harus dilakukan dengan menggunakan sistem online. Untuk pembelajaran Pendidikan Profesi Guru (PPG) PAI, telah dirancang pembelajaran online melalui website www.siagapemdis.com yang 
didesain oleh Direktorat Pendidikan Agama Islam kementerian agama dengan mengadopsi kebutuhan mahasiswa dalam belajar terutama prinsip tugas mandiri dan terstruktur.

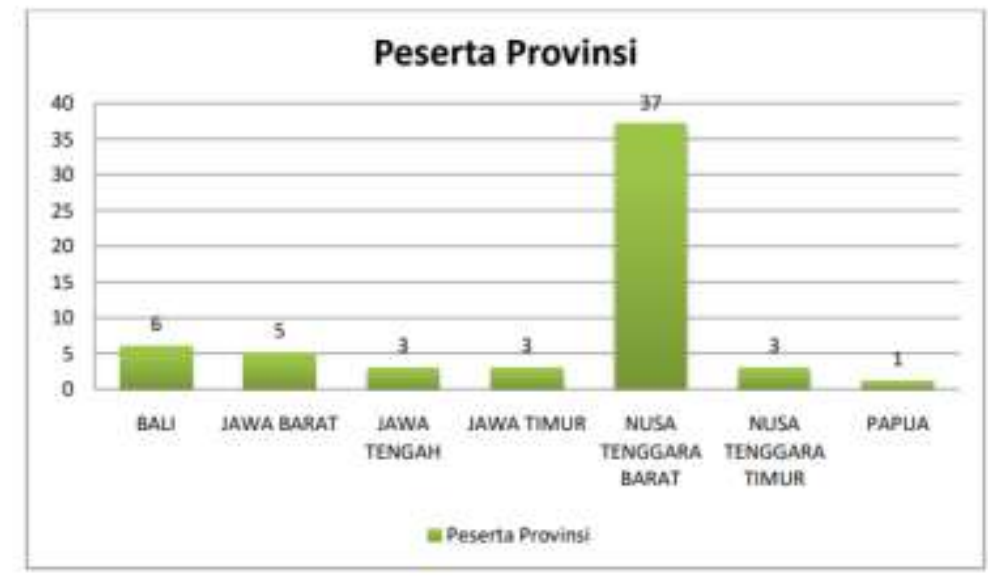

Gambar 2 Data Peserta PPG PAI berdasarkan asal Provinsi

Dari tabel di atas dapat diuraikan bahwa guru dalam jabatan yang mengikuti pendidikan profesi di LPTK UIN Mataram berjumlah 58 orang yang berasal dari tujuh (7) provinsi, yaitu Bali, Jwa Barat, Jawa Tengah, Jawa Timur, Nusa Tenggara Barat, Nusa Tenggara Timur dan Papua.

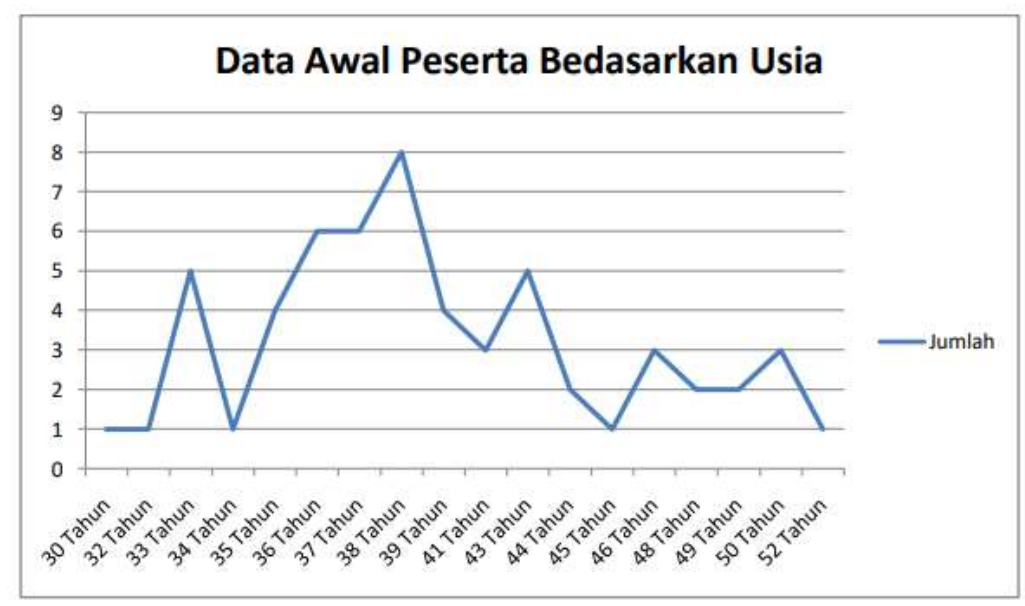

Gambar 3 Data Peserta PPG PAI Berdasarkan Usia 
Tabel di atas menggambarkan bahwa 58 orang guru Pendidikan Agama Islam yang mengikuti pendidikan profesi guru di LPTK UIN Mataram sangat beragam dari segi usia. Mulai dari usia 30 tahun sampai dengan 52 tahun.

Menurut Permenristekdikti Nomor 55 tahun 2017 Pasal 20 ayat (11) Beban belajar Program PPG Daljab paling sedikit 24 (dua puluh empat) sks. Mengikuti Permenristekdikti ini pada Pasal 20 ayat (6), kurikulum PPG Daljab dengan total 24 sks ini diurai ke dalam tiga bentuk pembelajaran, yaitu kuliah-teori (pendalaman materi akademik), lokakarya, dan praktik pengalaman lapangan (PPL). Materi akademik mencakup dua (2), yaitu akademik pedagogik dan akademik bidang studi/profesional.

Materi akademik pedagogik dengan materi pokok Pendidikan dan Profesi Pendidik, diarahkan untuk memberikan penguatan tentang dasar-dasar ilmu pendidikan dan prinsip-prinsip guru sebagai profesi. Sedangkan materi pokok untuk akademik bidang studi/profesional tidak hanya mencakup materi-materi keilmuan, melainkan dikaitkan dengan cara pembelajarannya, atau dikaitkan dengan penerapan prinsip TPACK (Tenological Pedagogical and Content Knowledge).

Lokakarya berupa kegiatan revieu pendalaman Materi Modul, pengembangan/penyusunan perangkat pembelajaran, peerteaching dan proposal Penelitian Tindakan Kelas (PTK). Atas dasar pertimbangan bahwa mahasiswa PPG Dalam jabatan sudah mempunyai pengalaman mengajar (menjadi guru di sekolah), maka ketiga bentuk pembelajaran ini diberi bobot belajar (sks) sebagai berikut:

\begin{tabular}{clcc}
\hline No & \multicolumn{1}{c}{ Materi } & Bobot (Sks) & Kode \\
\hline 1. & Pendalaman Materi & 10 & MAN \\
2. & Lokakarya & 8 & LOK \\
3. & PPL & 6 & PPL \\
\hline
\end{tabular}

Berdasarkan beberapa pertimbangan, antara lain tugas mengajar guru di sekolah dan kemampuan LPTK pada umumnya, maka pendalaman materi 
dilakukan secara online (daring). Dengan demikian, pendalaman materi akademik pedagogik dan akademik profesional, dilakukan sebagai pembelajaran DARING, sedangkan lokakarya dan PPL tetap dilakukan dengan tatap muka di LPTK (PPL dilakukan di sekolah-sekolah di sekitar lokasi LPTK).

Struktur kurikulum Program PPG dalam Jabatan Guru PAI dapat ditabulasikan sebagai Tabel berikut.

\begin{tabular}{|c|c|c|c|c|c|}
\hline \multirow{2}{*}{ Kode } & \multirow{2}{*}{ Mata Kegiatan PPG } & \multirow{2}{*}{ Sks } & \multicolumn{3}{|c|}{ Kategori } \\
\hline & & & $\mathbf{T}$ & $\mathbf{P}$ & $\mathbf{L}$ \\
\hline DAR1 & $\begin{array}{l}\text { Pendalaman materi Pendidikan dan Profesi } \\
\text { Pendidik }\end{array}$ & 4 & 4 & & \\
\hline DAR2 & $\begin{array}{l}\text { Pendalaman materi bidang studi dengan } \\
\text { menerapkan } \\
\text { prinsip TPACK }\end{array}$ & 6 & 6 & & \\
\hline LOK1 & $\begin{array}{l}\text { Reviu dan diskusi hasil pendalaman materi melalui } \\
\text { pembelajaran daring }\end{array}$ & 1 & & 1 & \\
\hline LOK2 & $\begin{array}{l}\text { Pengembangan Perangkat Pembelajaran dan } \\
\text { PeerTeaching }\end{array}$ & 6 & & 6 & \\
\hline LOK3 & $\begin{array}{l}\text { Penyusunan Perencanaan } \text { Penelitian Tindakan } \\
\text { Kelas (PTK) }\end{array}$ & 1 & & 1 & \\
\hline \multirow[t]{3}{*}{ PPL } & Praktik Pengalaman Lapangan (PPL) & 6 & & & 6 \\
\hline & Sub Jumlah & 24 & 6 & 8 & 6 \\
\hline & Total & & & 20 & \\
\hline
\end{tabular}

Gambar 4 Tabel Struktur Kurikulum Program PPG DALJAB

Design Pendalaman Materi (MAN) PPG PAI Kuota 2019 LPTK UIN Mataram dilaksanakan selama 3 bulan, yakni 17 Juni 2019 sampai dengan 10 September 2019. Pendalaman materi menggunakan pola DARING (Dalam Jaringan) yang melakukan pembelajaran melalui www.siagapendis.com dengan membahas modul yang terdiri dari: 7 Modul Pedagogik dan 7 Modul Profesional. Pada akhir pembelajaran Pendalaman Materi melalui DARING kementerian Agama mengumumkan peserta yang dinyatakan Lulus dan berhak mengikuti tahapan PPG berikutnya, yaitu Lokakarya. Standar nilai kelulusan mahasiswa adalah 78, dan menghitung keaktifan dalam jumlah Login, Durasi Login, Keaktifan Mahasiswa di Forum, Tugas Formatif dan 
Tugas Akhir Modul.

Dalam fase pembelajaran dalam jaringan (DARING) ini, LPTK UIN Mataram berhasil lulus dengan angka 100 \% yaitu 58 orang peserta. Adapun jadwal pelaksanaan pendalaman Materi dalam sistem DARING adalah:

\begin{tabular}{|c|l|c|l|}
\hline No. & Modul & Pekan & Tanggal Mulai \\
\hline 1 & PAI - HADIS & 1 & $17-06-2019$ \\
\hline 2 & PAI - AL QUR'AN & 2 & $23-06-2019$ \\
\hline 3 & PAI - AKIDAH & 3 & $29-06-2019$ \\
\hline 4 & PAI - AKHLAK & 4 & $05-07-2019$ \\
\hline 5 & PAI - FIQIH & 5 & $11-07-2019$ \\
\hline 6 & PAI - SKI & 6 & $17-07-2019$ \\
\hline 7 & PAI - PENDIDIKAN AGAMA ISLAM KONTEMPORER & 7 & $23-07-2019$ \\
\hline 8 & PAI - STRUKTUR DAN POLA PIKIR KEILMUAN PAI & 8 & $29-07-2019$ \\
\hline 9 & PEMBELAJARAN ABAD 21 & 9 & $04-08-2019$ \\
\hline 10 & TEORI BELAJAR DAN PEMBELAJARAN & 10 & $10-08-2019$ \\
\hline 11 & KURIKULUM DAN STRATEGI PEMBELAJARAN & 11 & $18-08-2019$ \\
\hline 12 & PENGEMBANGAN PROFESI GURU & 12 & $24-08-2019$ \\
\hline 13 & PERKEMBANGAN PESERTA DIDIK & 13 & $30-08-2019$ \\
\hline 14 & EVALUASI PEMBELAJARAN & 14 & $05-09-2019$ \\
\hline
\end{tabular}

Gambar 5 Jadwal Pembahasan 14 Modul melalui online

Dari 14 modul tersebut didesain dalam pembelajaran online, 1 modul dibahas dalam 1 minggu. 1 Rombongan belajar diisi minimal 10 orang mahasiswa pendidikan profesi guru (PPG) Pendidikan Agama Islam, sehingga 58 orang mahasiswa Pendidikan Profesi Guru (PPG) UIN Mataram dibagi menjadi enam rombongan belajar (Kelas ABCDEF). Mekanisme pembagian kelas mahasiswa, dosen dan peng-upload-an modul di atur oleh pengelola PPG melalui petugas admin IT.

Di awal pembelajaran, dosen atau instruktur mengupload rencana pembelajaran semester (RPS) permodul. Setiap Modul terdiri dari minimal 4 Kegiatan Belajar (KB). Admin Pendidikan Profesi Guru dari LPTK biasanya telah mengupload Modul dalam aplikasi www.siagapendis.com, selanjutnya instruktur dan mahasiswa beriteraksi dan berkomunikasi melalui menu dan fitur pembelajaran, seperti menu resume per $\mathrm{KB}$, mendownload materi berupa file pdf, powerpoint, dan menonton video pembelajaran. Mahasiswa pendidikan profesi guru PAI juga diwajibkan mengirim tugas resume, tugas 
formatif dan sumatif melalui website pembelajaran online PPG. Di samping itu, Dosen dan mahasiswa juga melakukan komunikasi dan diskusi melalui menu diskusi dengan melakukan tanya jawab yang dapat direspon oleh seluruh anggota rombongan belajar di kelas online tersebut.

COTOH KONTRAK KULIAH DARING

Modul : Sejarah Kebudayaan Islam (SKI)

Instruktur : Dr. Abdul Quddus, MA

Waktu : Rabu, 17 Juli $2019-$ Senin 22 Juli 2019

\begin{tabular}{|c|c|c|c|c|c|c|c|}
\hline JAM & $\begin{array}{c}\text { Rabu } \\
17 \text { Juli } \\
2019\end{array}$ & $\begin{array}{c}\text { Kamis } \\
18 \text { Juli } \\
2019\end{array}$ & $\begin{array}{l}\text { Jumat } \\
19 \text { Juli } 2019\end{array}$ & $\begin{array}{l}\text { Sabtu } \\
\text { 20 Juli } 2019\end{array}$ & $\begin{array}{l}\text { Ahad } \\
\text { 21 Juli } 2019\end{array}$ & $\begin{array}{l}\text { Senin } \\
\text { 22. Juli } 2019\end{array}$ & KET \\
\hline $14.00-15.00$ & $\begin{array}{l}\text { Mengerjakan } \\
\text { Soal Pre test }\end{array}$ & $\begin{array}{l}\text { Penyerahan } \\
\text { Resume KB- } \\
1\end{array}$ & $\begin{array}{l}\text { Penyerahan } \\
\text { Resume } \mathrm{KB}-2\end{array}$ & $\begin{array}{l}\text { Penyerahan } \\
\text { Resume KB-3 }\end{array}$ & $\begin{array}{l}\text { Penyerahan } \\
\text { Resume KB-4 }\end{array}$ & $\begin{array}{l}\text { Test Akhir } \\
\text { Modul }\end{array}$ & $\begin{array}{l}\text { Pelakssanaan } \\
\text { Post Test Modul } \\
\text { Berlangsung } \\
\text { Serentak }\end{array}$ \\
\hline $15.00-16.00$ & \multirow{3}{*}{$\begin{array}{c}\text { Kontrak } \\
\text { belajar } \\
\text { Menvepakati } \\
\text { belajar } \\
\text { DARING, } \\
\text { Dosen } \\
\text { Memberikan } \\
\text { Perintah } \\
\text { Download } \\
\text { Materi }\end{array}$} & \multirow[t]{2}{*}{$\begin{array}{l}\text { Diskusi } \\
\text { Video, } \\
\text { Artikel atau } \\
\text { PPT Online } \\
\text { KB-1 }\end{array}$} & \multirow[t]{2}{*}{$\begin{array}{l}\text { Diskusi Video, } \\
\text { Artikel atau } \\
\text { PPT Online } \\
\text { KB-2 }\end{array}$} & \multirow[t]{2}{*}{$\begin{array}{l}\text { Diskusi Video, } \\
\text { Artkel atau } \\
\text { PPT Online } \\
\text { KB-3 }\end{array}$} & \multirow[t]{2}{*}{$\begin{array}{l}\text { Diskusi Video, } \\
\text { Artikel atau } \\
\text { pPT Online } \\
\text { KB-4 }\end{array}$} & \multirow{2}{*}{$\begin{array}{l}\text { Tugas } \\
\text { Tambahan } \\
\text { Yang } \\
\text { Tidak } \\
\text { Mencapal } \\
\text { Target } \\
\text { kelulusan } \\
\text { Modul }\end{array}$} & \multirow{2}{*}{$\begin{array}{l}\text { Dosen dan } \\
\text { mahasiswa } \\
\text { diskusi intens } \\
\text { secara online. } \\
\text { Sernua hasil } \\
\text { diskusi dan } \\
\text { komentar akan } \\
\text { direksm dan } \\
\text { dinilial dosen }\end{array}$} \\
\hline $16.00-17.00$ & & & & & & & \\
\hline $18.00-19.00$ & & $\begin{array}{l}\text { Tes Formatif } \\
\text { KB-1 }\end{array}$ & $\begin{array}{l}\text { Tes Formatif } \\
\text { KB-2 }\end{array}$ & $\begin{array}{l}\text { Tes Formatif } \\
\text { KB-3 } \\
\end{array}$ & $\begin{array}{l}\text { Tes Formatif } \\
\text { KB-4 }\end{array}$ & & \\
\hline $20.00-21.00$ & $\begin{array}{l}\text { Penugasan } \\
\text { Membaca } \\
\text { KB-1 }\end{array}$ & \begin{tabular}{|l|} 
Penugasan \\
Membaca \\
KB-2
\end{tabular} & $\begin{array}{l}\text { Penugasan } \\
\text { Membaca } \\
\text { KB-3 }\end{array}$ & \begin{tabular}{|l|} 
Penugasan \\
Membaca \\
KB-4
\end{tabular} & $\begin{array}{l}\text { Review Pre } \\
\text { Test dan } \\
\text { Penambahan } \\
\text { tugas bagi } \\
\text { vang } \\
\text { kurang } \\
\end{array}$ & & \\
\hline $21.00-22.00$ & $\begin{array}{l}\text { Membuat } \\
\text { Resume } 1\end{array}$ & \begin{tabular}{|l}
$\begin{array}{l}\text { Membuat } \\
\text { Resume KB- } \\
2\end{array}$ \\
\end{tabular} & $\begin{array}{l}\text { Membuat } \\
\text { Resume KB-3 }\end{array}$ & \begin{tabular}{l|} 
Membuat \\
Resume KB-4
\end{tabular} & $\begin{array}{l}\text { Tugas Mandiri } \\
\text { Perbaikan }\end{array}$ & & \\
\hline
\end{tabular}

Mataram, 17 Juli 2019

Instruktur

Dr. Abdul Quddus, MA

Gambar 6 contoh kuliah daring 1 minggu untuk 1 modul

Semua tahapan pembelajaran online tersebut dinilai dan diberikan grade oleh instruktur melalui menu penilaian. Selaian tahapan tugas dan uji dalam proses, menu pembelajaran online juga dilengkapi dengan soal pretest dan tes akhir modul. Bagi mahasiswa yang tidak memenuhi standar nilai, maka diwajibkan menambah tugas melalui menu tugas. 


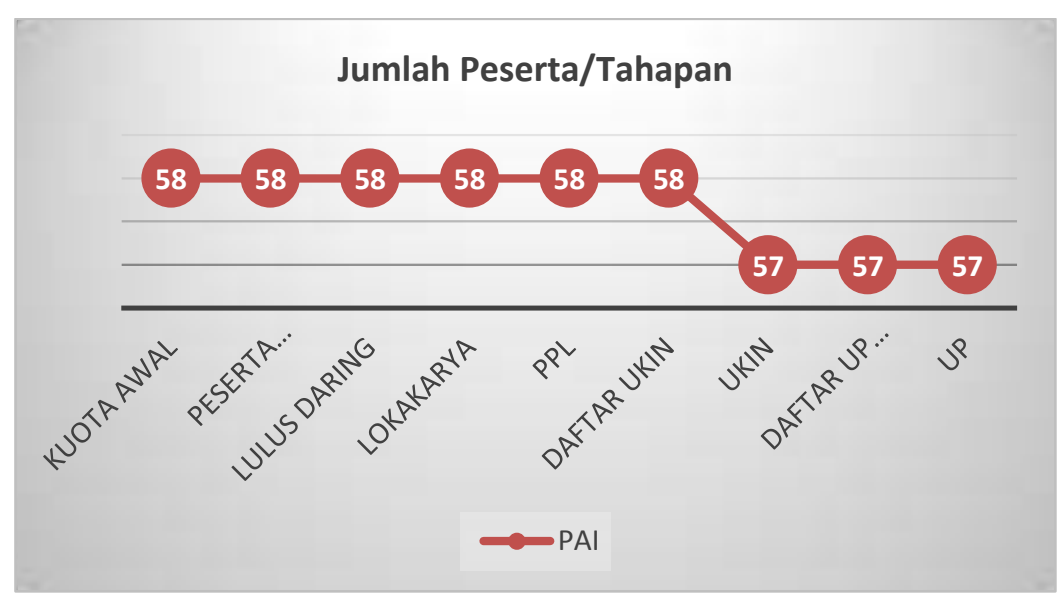

Gambar 7 Grafik Keaktifitan Peserta dalam Pembelanjaran Online

Tahap selanjutnya, Program PPG PAI memasuki lokakarya perangkat pembelajaran melalui tatap muka di kampus. Desain lokakarya dapat digambarkan dalam tabel di bawah ini:

\begin{tabular}{|c|c|c|c|c|}
\hline Kode & Mata Keg PPG & SKS & $\begin{array}{l}\text { Setara } \\
\text { JP/hari }\end{array}$ & 5 minggu \\
\hline \multirow[t]{2}{*}{ LOK1 } & Loka Karya 1: & 1 & $32 / 4 \mathrm{hr}$ & $\begin{array}{l}* 8,5 \text { jam per hari, } \\
\text { dengan } 6 \text { hari kerja }\end{array}$ \\
\hline & Review Materi Pembelajaran Daring & & & $* 10,2$ jam per hari \\
\hline \multirow[t]{3}{*}{ LOK2 } & Loka Karya 2: & 6 & $192 / 24$ & dengan 5 hari kerja \\
\hline & Pengembangan Perangkat Pembelajaran & & $\mathrm{hr}$ & \\
\hline & $\begin{array}{l}\text { dengan pendekatan saintifik dan penilaian holistik- } \\
\text { otentik dan implementasi di peer teaching }\end{array}$ & & & \\
\hline LOK3 & Loka Karya 3: Proposal PTK & 1 & $32 / 4 \mathrm{hri}$ & \\
\hline \multirow[t]{2}{*}{ PPL } & Praktik Pengalaman Lapangan & 6 & & \\
\hline & Jumlah & 14 & & \\
\hline
\end{tabular}

Gambar 8 Design Lokakarya selama 32 hari

Dalam tiga tahapan lokakarya tersebut di atas, Mahasiswa PPG Pendidikan Agama Islam dituntut berhasil mendesain perangkat 
pembelajaran sesuai jenjang dimana mereka menjadi Guru baik di Sekolah Dasar, Sekolah Menengah Pertama dan Sekolah menengah Atas. Pengebangan perangkat pembelajaran dilakukan denga pendekatan saintiifik dan penilaian holistik-otentik. Selanjutnya peserta Program PPG melakukan pemaparan hasil perangkat pembelajaran melalui skenario peer teaching tahap I di depan teman sejawat di masing-masing rombongan belajar lalu dievaluasi oleh dua dosen yang mengevaluasi secara bersamaan di kelas. Hasil Peerteaching tahap 1 kemudian diperbaiki sesuai hasil masukan teman sejawat dan dosen lokakarya. Pada tahap berikutnya, perangkat pembelajaran yang telah disusun dan dipresentasikan dalam tahap lokakarya, kemudian digunakan dalam tahap berikutnya yaitu Praktek Pengalaman Lapangan (PPL) di sekitar 8 sekolah mitra, yang ada di sekitar Kota Mataram. (Informasi tersebut berdasar penjelasan Sekretaris PPG H. Fathul Maujud).

Menurut wawancara beberapa mahasiswa PPG PAI, mereka mengakui bahwa dalam praktek peer teaching, mahasiswa menemukan kelemahan rata-rata mereka pada proses desain perangkat pembelajaran dengan berbasis teknologi, misalnya media pembelajaran video atau animasi pembelajaran pendidikan agama Islam. Walaupun bebera diantara mereka sudah berhasil misalnya pembuatan video sederhana tentang shalat, penyelenggaran jenazah dan materi pendidikan agama lainnya. (Penjelasan mahasiswa PPG PAI: Baiq Urian dan Kamran Zaed)

Tahap selanjutnya adalah PPL. Kegiatan Praktik Pengalaman Lapangan (PPL) bertujuan memberikan bekal pengalaman dan pengetahuan praktis kependidikan sebagai usaha untuk mewujudkan guru profesional yang memiliki empat kompetensi yaitu kompetensi paedagogik, kepribadian, profesional, dan sosial sesuai Undang-undang Guru dan Dosen No.14 tahun 2005 dan PP No.32 tahun 2013 tentang perubahan atas Peraturan Pemerintah Nomor 19 tahun 2005 tentang Standar Nasional Pendidikan.

Praktik Pengalaman Lapangan (PPL) adalah salah satu rangkaian dari 
proses Pendidikan Profesi Guru. PPL mencakup kegiatan praktik pembelajaran dan non-pembelajaran, serta praktik Penelitian Tindakan Kelas (PTK). Tujuan khusus kegiatan praktik non-pembelajaran di sekolah adalah mendalami, berpartisipasi, dan/atau mempraktikkan kegiatan-kegiatan nonpembelajaran yang meliputi: administrasi sekolah, kultur sekolah, ekstrakurikuler (kepramukaan, UKS, majalah dinding, dll), rapat-rapat sekolah, layanan bimbingan dan konseling bagi mahasiswa. Tujuan kegiatan praktik PTK adalah memperbaiki praktik dan meningkatkan mutu pembelajaran di sekolah. PPL menerapkan pendekatan supervisi klinis dan tindakan reflektif dengan prinsip berkelanjutan, terstruktur, dan relevan dengan perangkat pembelajaran. Supervisi Klinis adalah suatu bentuk bimbingan profesional yang diberikan kepada peserta PPG sesuai dengan kebutuhannya untuk meningkatkan profesionalitas sebagai guru.

Kegiatan PPL mahasiswa PPG dilaksanakan setelah mahasiswa menyelesaian lokakarya pengembangan perangat pembelajaran dan peer teaching dengan beban belajar 6 sks.

\begin{tabular}{llcc}
\hline No & \multicolumn{1}{c}{ Kegiatan } & Bobot sks & Lama Hari* $^{*}$ \\
\hline 1 & $\begin{array}{l}\text { Persiapan, eksplorasi sumber } \\
\text { belajar dan konsultasi }\end{array}$ & 1,5 & 7,2 \\
2 & $\begin{array}{l}\text { Implementasi Hasil Lokakarya ke } \\
\text { dalam Pembelajaran }\end{array}$ & 3,5 & 17,0 \\
3 & $\begin{array}{l}\text { Penambahan wawasan } \\
\text { pengelolaan sekolah dan kegiatan } \\
\text { ekstrakurikuler }\end{array}$ & 1,0 & 4,8 \\
$\quad$ Jumlah & 6,0 & 29,0 \\
\hline
\end{tabular}

Gambar 9 Implementasi bobot PPL 6 sks

PPL dilaksanakan di sekolah mitra. Adapun kriteria sekolah/madrasah mitra: pertama; sekolah mitra sebagai lokasi PPL PPG sekurang-kurangnya memiliki peringkat akreditasi B. Kedua; terikat dalam nota kesepahaman antara dinas pendidikan kabupaten/kota dengan LPTK penyelenggara PPG yang masih berlaku dan pola kemitraan bersifat kolaboratif.

PPL untuk program Pendidikan Profesi Guru dilaksanakan 
selama tiga minggu. Dengan bobot 6 sks. Pelaksaannya dimulai dari tanggal 21 Oktober s/d 09 Nopember 2019. Adapun laokasi PPL terdiri dari 8 Sekolah. Untuk jenjang SD ada 4 sekolah, dan SMP berjumlah 2 Sekolah dan untuk tingkat SMA berjumlah 2 sekolah. Jumlah total lokasi PPL adalah 8 Sekolah. Sekolah lokasi PPL dipusatkan pada Kota Mataram. Berikut adalah nama-nama sekolah berdasarkan Jenjang dan jumlah mahasiswa PPL: SDN 2 Cakra negara, SDN 5 Mataram, SDN 6 Mataram, SDN 13 Mataram, SMPN 1 Mataram, SMPN 2 Mataram, SMAN 2 Mataram dan SMAN 5 Mataram. (Penjelasan Ketua Uji Kinerja, Syamsul Arifin)

Dari pemaparan di atas, dapat simpulkan bahwa implementasi TPACK di LPTK UIN Mataram dilakukan dengan model Blended Learning yaitu mensinergikan pembelajaran online atau dalam jaringan melalui sigapendi.com dengan pembelajaran offline berupa tatap muka (face to face) terutama dalam tahap lokakarya desain perangkat pembelajaran dan praktek pengalaman lapangan (PPL).

\section{KESIMPULAN}

Pendidikan profesi guru PAI UIN Mataram telah menerapkan TPACK yang menggabungkan teknologi, pedagogi dan konten dalam pembelajaran online melalui aplikasi www.siagapendis.com Direktorat PAI Kemenag RI. Modul bidang profesional dan pedagogi telah dibahas dengan pendekatan teknologi. Mahasiswa Pendidikan Profesi Guru PAI telah menerapkan pembelajaran online dalam manajemen kelas online, download dan baca modul, baca materi pdf, powerpoint kemudian resume dan upload tugas, aktif dalam diskusi online dan mengikuti ujian online dalam bentuk pretest, tugas formatif, tugas sumatif, dan tugas akhir modul. Pembelajaran model TPACK tersebut telah mengembangkan kompetensi mahasiswa pendidikan profesi guru PAI menjadi guru profesional dan komptensi pedagogi dan profesional dengan merancang pembelajaran berbasis teknologi. Dalam implementasi TPACK online, PPG PAI UIN Mataram juga menerapkan Blended Learning, 
yaitu mensinergikan pembelajaran online tersebut dengan offline yaitu pembelajaran tatap muka terutama dalam Lokakarya desain perangkat pembelajaran, penelitian tindakan kelas (PTK) dan PPL. UIN Mataram memperoleh nilai cukup maksimal dalam Uji Kompetensi Mahasiswa PPG baik Uji Kinerja maupun Uji Pengetahuan. Untuk Uji Kinerja LPTK UIN mataram berhasil lulus 99\% dan untuk Uji Pengtahuan (UP) mahasiswa LPTK UIN Mataram lulus sejumlah 39 Orang $(68,42 \%)$.

\section{DAFTAR PUSTAKA}

Bozkurt, E. (2014). TPACK Levels of Physics And Science Teacher Candidates: Problem And Possible Solutions. Asiapacific Forum On Science Learning And Teaching , 15(2), 1-22

Interview Mahasiswa PPG PAI LPTK UIN Mataram

Interview Pengelola PPG PAI LPTK UIN Mataram

Koehler, M. J., Mishra, P., Ackaoglu, M.,\&Rosenberg, J. M. (2013). The Techonological Pedagogical Content Knowledge Framework For Teachers And Teacher Educators. Commonwealth Educational Media Centre For Asia Teacher. No. 9702. Jan 14,1997

Lexy J. Moleong, Metodologi Penelitian Kualitatif (Bandung: Remaja Rosdakarya, 2000) cet. 18 , h.5

Luthfia Ulva Irmita Dan Sri Atun, Pengembangan Perangkat Pembelajaran Menggunakan Pendekatan Tpack Untuk Meningkatkan Literasi Sains, Jurnal Tadris Kimiya 2, 1 (Juni 2017): 84-90. Tersedia online di https://journal.uinsgd.ac.id/index.php/tadris-kimiya/article/view/1363

Mattew B. Miles dan A. Michael Huberman, Analisis Data Kualitatif (terj. Tjejep Rohendi Rohidi, (Jakarta: UI-Press, 1992) h.19

Panduan PPG Direktorat Pembelajaran Ditjen Belmawa Kementerian Riset, Teknologi, dan Pendidikan Tinggi tahun 2018

Petunjuk Teknis Pelaksanaan PPG Dalam Jabatan Direktorat Guru dan Tenaga Kependidikan (GTK) Kementerian Agama RI Tahun 2018 
Profil dan Pedoman PPG LPTK UIN Mataram

Tatat Hartati Dkk, Technological Pedagogical Content Knowledge (TPACK) Dalam Rangka Peningkatan Kualitas Pembelajaran Mahasiswa PPG SD Prajabatan. Jurnal Edutech 18 (2), 2019. Tersedia online di https://ejournal.upi.edu/index.php/edutech/article/view/15092

Tohir, Mohammad. 2019. Hasil PISA Indonesia Tahun 2018 Turun Dibanding Tahun 2015. Tersedia Online: https://matematohir.wordpress.com/ 2019/12/03/hasil-pisa-indonesia-tahun-2018-turun-dibanding-tahun2015/ [03 Desember 2019] 